\title{
CARDIAC DISEASES AND SUBSTITUTIVE/REPARATIVE TECHNOLOGIES
}

\author{
UMBERTO ROSA *
}

ABSTRACT. - Several examples of implantable devices are here considered able to substitute or sustain important physiological functions which have been deteriorated or completely lost. To properly design and implement such devices very complex technological problems must be overcome. They concern the behaviour and the biocompatibility of the materials, the functioning in an hostile environment without possibility of maintenance and finally the need of "mimicking" closely the physiological functions which are not always perfectly known in all circumstances and conditions.

The specific needs arising from medicine towards technology are therefore very demanding so that they are stimulating advanced new solutions which in turn are determining significant advancements in various sectors with a strong crossdissemination effects.

Three outstanding examples are here considered: the mechanical cardiac valve, the artificial reinforcement of coronaries (stent) and the cardiac defibrillator. For all these cases, the specific problems involved are analysed and the degree of success with which the technology has satisfied the medical requirements are discussed.

\section{RIASSUNTO}

Vengono presi in esame alcuni casi di apparati impiantabili, destinati a sostituire o a sostenere funzioni fisiologiche danneggiate o perdute. Lo sviluppo di tali apparati presenta problemi tecnologici di elevata complessità, al livello p.es. del com-

* SNIA - Milano. 
portamento dei materiali, del funzionamento in ambiente ostile senza possibilità di manutenzione, della necessità di "mimare" da vicino funzioni fisiologiche non sempre note al livello della loro struttura fine. Le esigenze della medicina nei confronti della tecnologia sono quindi tali da stimolare soluzioni avanzate che, a loro volta, determinano progressi in vari settori, attivando effetti di fertilizzazione. Vengono esaminati e discussi tre casi; la valvola cardiaca meccanica, il rinforzo artificiale delle coronarie (stent) ed il defibrillatore impiantabile, analizzandone le specificità ed il grado di successo con cui la tecnologia ha risposto alle attese della medicina. 